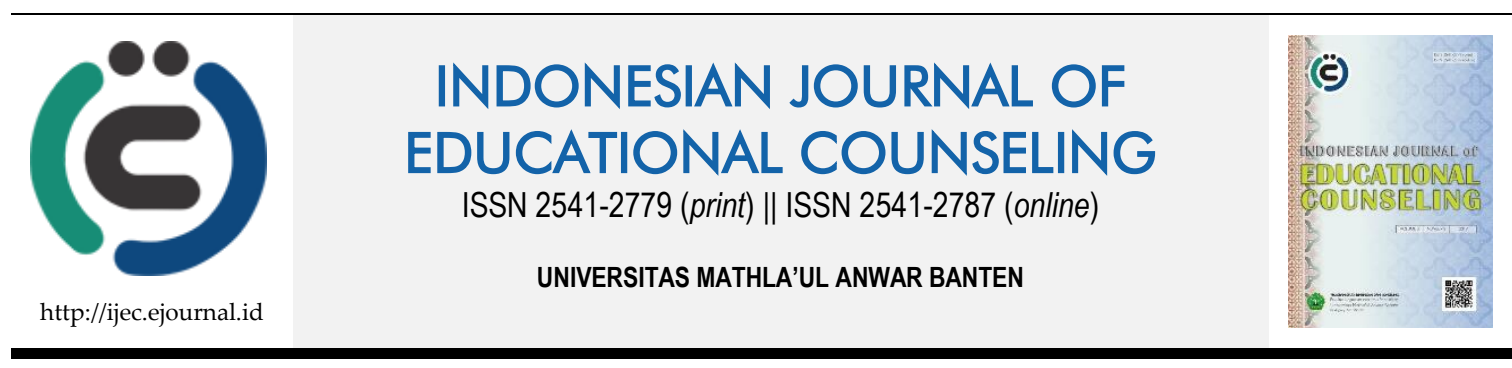

Research Based Article

\title{
"It is Important to Prepare Ourselves for the Future Career": A Study of Indonesian Student's Self-Directed Experience on Career Exploration
}

\author{
Ragwan Mohsen Alaydrus ${ }^{1}$, Siti Rafiah Abd. Hamid ${ }^{2}$ \\ 1, 2 International Islamic University Malaysia (IIUM)
}

\begin{tabular}{ll}
\hline Article History & ABSTRACT \\
\hline Received: 31.05 .2019 & Lack of career exploration leads to career indecisiveness among Indonesian \\
Received in revised form: & high school students. According to some studies, successful career exploration \\
20.06 .2019 & is determined by students' initiative. However, no consistent answer about \\
Accepted: 27.06 .2019 & factors that make the students self-directedly engage in career exploration. This \\
Available online: 22.07 .2019 & study is aimed to explore student's self-directedness during the career \\
& exploration, including the factors that encourage student's career exploratory \\
& behavior. This single case study used semi-structured interview and document \\
& analysis to investigate the experience of one Indonesian high school student. \\
& Two themes emerged from the data: involvement factor in career exploration, \\
& which determined by internal and external influence, and qualities of self- \\
& directedness, which is reflected by the employment of strategies and self- \\
& awareness. Recommendation for parents and educators to provide exposure to \\
& various activities, explicit teaching of self-directed learning and related skills is \\
& also essential to build students' initiative in career exploration.
\end{tabular}

KEYWORDS: Career Exploration, High School Student, Self-Directed Learning.

DOI: $10.30653 / 001.201932 .87$

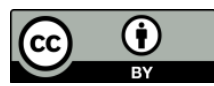

This is an open access article distributed under the terms of the Creative Commons Attribution 4.0 International License, which permits unrestricted use, distribution, and reproduction in any medium, provided the original work is properly cited. ๑) 2019 Ragwan Mohsen Alaydrus, Siti Rafiah Abd. Hamid.

\section{INTRODUCTION}

Career exploration is a lifelong process which involves students' effort in exploring themselves as well as the career choice and its requirements. Career exploration will be more intense when the students are moving to higher education. In Indonesia, schools accommodate career exploration by providing guidance and counseling service, with a mission to facilitate the students in exploring and making career decision throughout students' lifetime. Counseling teachers, as the facilitator have a role in conducting faceto-face classes and individual career counseling to prepare students with skills and information about their future career. Even though the serial intervention has been done to train students with career exploration and decision making, there are some Indonesian

${ }^{1}$ Corresponding author's address: International Islamic University Malaysia (IIUM), P.O. Box 10, 50728 Kuala Lumpur, Malaysia; Email: gwan.aydruspro@gmail.com 
students in confusion when it comes to choosing a specialization in university (Lopulalan, 2016). This fact does not reflect a failure in career intervention at school. Zulkaida and colleagues explained that students' effort in collecting information about the career choice, acknowledging their strengths and weaknesses, and overcoming the obstacles would determine the success of career exploration (Zulkaida et al., 2017). From here, both the teachers and students should realize the need for students' active participation in creating their career aspiration. Instead of having a teacher with full control, schools have to encourage the student to build self-determination in learning, including career exploration. The teacher can guide students to develop college readiness during the career exploration by exposing them with various activities, but the students will be the one who responsibly applies and monitor the strategy (Agran, 1997).

The skill of controlling the learning process is strongly related to self-directed learning (SDL). In SDL, students take responsibility for their learning by identifying their needs, formulating learning goals, finding appropriate material resources or others' help, manage themselves by using learning strategies, monitoring their progress and evaluating the learning outcomes (Knowles, 1975). Therefore, SDL skills are very crucial to equip the students with the ability to plan their career path, not only after school but also in their professional life.

Boyer et al. (2014) stressed SDL as a tool of lifelong learning by relating it with several qualities such as locus of control, motivation, and self-efficacy. Further, the role of the instructor is essential to encourage students' motivation to involve in SDL. Dozier, Sampson, Lenz, Peterson, and Reardon (2015) found that SDL intervention can enhance exploratory career behavior. In other word, guidance and resources are essential to provoke independent inquiry of the students. Conversely, the SDL quality can influence students' performance in accomplishing a task. Seifert, Newbold, and Chapman (2016) stated that when students were given a project, those with high SDL will run for accomplishment while the rest who have lack experience of SDL will keep asking a question instead of starting the task. Based on the importance of SDL, this current study is aimed to investigate student's performance of self-directedness during the career exploration. The findings will be beneficial to suggest the appropriate scaffolding strategies of SDL in guidance and counseling service.

\section{Statement of Problem}

Self-directed learning (SDL) is strongly suggested to be inculcated more intensively in the educational process to encourage students' initiative in acquiring skills and knowledge (Rotherham \& Willingham, 2010). SDL has been identified as one of the factors that increase the probability of career exploration involvement by individuals together with psychological confidence, and other positive feelings about the self and the context (Taveira \& Moreno, 2003). A study by Betz and Voyten (1997) regarding the social cognitive model stated that self-efficacy and career outcome expectations are the predictors of students' involvement in career exploration. The similar finding brought by Blustein and Noumair (1996) that goal-directedness and self-efficacy foster careerexploratory behavior. Self-efficacy has been identified as a dominant predictor even though there is a specific relationship between goal-directness and efficacy in career decision making. They highlighted, "following this observation; it is conceivable that individuals who have internalized goals and values may find it possible to experience the 
confidence that fosters an active approach to career decision-making and career exploration" (Blustein \& Noumair, 1996, p. 201).

Above mentioned researches indicate that success in career decision making is a result of longtime personal development. Hence, it is essential to use the findings as a principle to create a comprehensive career guidance strategy. However, In Indonesia, researches that studied the approaches to develop students' career maturity were only conducted through the short-time intervention program. This current study aimed to qualitatively explore a student's self-directed experience in career exploration to provide a reference for longtime intervention for career guidance at school.

\section{Purpose of the Study}

The purpose of this qualitative case study is to investigate the influencing factor of a student's career exploration: what are the factors that contribute to foster student's career exploratory behavior until she reached her career choice. Besides that, this research aims to explore student's exploratory behavior with her attributes that may be appeared during her involvement in career exploration. The study will be significant to profile student's attributes, aspirations, and efforts during the career exploration. The information might be useful to understand the factors behind her active engagement in self and career exploration, her aspiration regarding parental and school support, and how the selfdirectedness takes place during the career exploration and decision making. All the information further will be used to understand students' career exploratory behavior and will be beneficial to improve career guidance and counseling approach.

\section{METHOD}

This single case study employed two instruments, semi-structured interview and documents analysis. The interview was done through phone call and chatting feature in Facebook messenger. Personal journal and participant's curriculum vitae for document analysis were sent through email to the researcher.

\section{Participant}

In this study, the researcher uses a purposeful sampling method by seeking participant with an abundant amount of information about the phenomenon of interest. The researcher used some criteria for identifying such participant, which are: 1) One high school student who studies in 12th grade (Kelas 12), 2) Decided student, who is characterized by her completed career plan and considered as having clear vocational aspiration.

\section{Data Collection}

Data collection procedures conducted in several stages. In the first stage, the researcher asked the student to fill a worksheet that contains some instructions to describe her career exploration and career plan. The worksheet was sent back to the researcher through email. After ensuring that the participant showed an ability to describe both her career plan and exploration clearly, researcher settled the interview session. In the second 
stage, in depth-interviews with open-ended questions were carried out for 1 hour 20 minutes in Bahasa Indonesia. The researcher asked about the student's experience in career exploration and how her strategies during the process. For example, she was asked, "Explain how you find the resources to help you in collecting career information" and "how you use them to be prepared for your future career?". The recorded conversations were transcribed into verbatim, and all the data was coded. The researcher identified subcategories to create categories and accumulated similar pattern into themes. Document analysis was utilized as supplementary data to provide additional information derived from the interview.

\section{RESULT AND DISCUSSION}

The researcher used a thematic approach to present the findings. Analysis from the series of data collection results in two emerging themes, they are involvement factor in career exploration and qualities of self-directedness during the process.

Table 1. Emerged Themes and Categories

\begin{tabular}{lll}
\hline No & Themes & Categories \\
\hline 1 & Involvement factor in career Exploration & Internal \\
& & External \\
2 & Qualities of self-directedness & Employing strategy \\
& & Self-awareness \\
\hline
\end{tabular}

\section{Involvement Factor in Career Exploration}

The researcher categorized student's involvement factor into two categories; internal which refers to individual motivation, and external, which includes influence from student's surrounding and inspired people.

\section{Internal}

It is revealed from the interview that the student has a personal aspiration to explore and prepare herself for a future career. Besides for ensuring the career readiness, the student gained benefit from career exploration for her self-fulfilling, she could attain achievement and followed her interest at the same time. She admitted during the interview:

That time I decided to choose medical study, then I thought I should learn Biology properly. It is better to start from now (since Junior High School). So, during that time, I tried to join Biology competitions. And Alhamdulillah because I enjoyed the learning, my achievements were satisfying in those competitions [Transcript no. 58].

When she was asked about her motivation to involve in many events and competitions, she explained the importance of being exposed to new circumstances, which are useful for self-improvement and network building: 
I had the opportunity to be exposed to a new situation that will train me to respond to new things; it also helps me to evaluate my self and gain more experience. By involving in the competition, I could be aware of global competition and the development of science and technology, so it drives me to improve my quality. Other than that, my participation allows me to build a connection with new people [Transcript no. 136].

The researcher found that a student's involvement in career exploration was based on her understanding of the importance of being prepared for a further career. According to the student, career and self-exploration is a vital step before deciding a career option. The student noticed the phenomena among the youths who face career disorientation in higher education:

It is miserable because since very early they did not have a clear objective so that they may lose their orientation during the study at university. They do not know what to do and end up in frustration [Transcript no. 66].

Not only that, the student showed her observation of future challenges and expressed her motivation to get prepared by developing essential skills:

For me, it is essential to prepare ourselves for our future career, because we know how intense global competition is. Notably, in Indonesia, many students are competing in university, and when they reach the workplace, they are also expected to show their capacity [Transcript no. 62].

The student has also highlighted the importance of early exposure and career exploration. Starting the involvement from a very young age will be better, because students may have a longer time to master particular skills:

So earliest the preparation, much more new things they can try. Instead of people who start when they are already in university. Because if they start earlier, just like from junior or senior high school, they will gain more experience. So, if they are actively developing skills in schools, when they reach university, they have already prepared themselves [Transcript no. 62].

\section{External}

Apart from the internal factor, student involvement in career exploration was supported and motivated by her significant others. The student mentioned how the parents provided support whenever she was participating in various events.

It was my own initiative to join any program, but I just told my parents what the things I need for preparation are. Moreover, Alhamdulillah my Dad and Mom always supported me in every research competition or program I participated [Transcript no. 132].

In career exploration, she admitted the role of her family and school:

The process of how I created my goals today cannot be separated from my family. They taught me to have targeted since a young age and to determine my goals for medical study ...Moreover, my school was always supporting me for my self-development. It made every process easy for me. They help to master the lesson and provide extra guidance. So, I think they both have a contribution to my success [Transcript no. 74]. 
Schools contributed to providing exposure and facilitating the students for exploration. Since junior high school, students were chosen to represent her school in some competition, and for that, she was allowed to take an extra session for study Biology outside the class. Many times school-supplied learning materials and motivated student to study regularly, which further made her felt encouraged. Schools facilitated the student to gain more new experiences by conducting a study tour outside the country and providing an opportunity to attend many events. In senior high school, the attention given was more focus on preparation for university. Research competition is another main program which is beneficial to improve student's skills of research on her favorite field. Regarding guidance during the school period, the student said:

My Junior high school provided learning assistance; we were directed and guided to master the subject. Our teachers also motivated us in studying and partaking in competitions [Transcript no. 154].

Furthermore, the student described how she got motivated by her role models, which were excellent students who succeed in their academic and vocational activities. She narrated about some of her role models:

There is a senior from the same school. She was in a different specialization, but I admire how she pursued her dream ... another one is a public figure, Maudi Ayunda. I amazed at how she managed her activities between her job as an actress and singer, and at the same time studied at Oxford University. Not only she achieved her dream in education; she had other targets to reach while her talents were also improving [Transcript no. 78].

The student was inspired in how the role models are working hard to achieve their targets, while they also develop self-management skills to handle and balance their activities. Apart from that, the student articulated her admiration to her father, whereby he is the most inspirational figure for the student. From him, the student learned how to be persistent and consistent in pursuing the target.

I love his hardworking; it really inspires me. So, when I feel tired, lazy, I just remember how he put his heart to his works, I would be motivated [Transcript no. 78].

\section{Qualities of Self-Directedness}

Two categories reflect student's self-directedness in career exploration. Selfdirectedness means how she has her initiative to plan and monitor her activity and understand herself. The self-directedness was shown by the student's self-awareness and the strategies she used for career exploration.

\section{Employing Strategy}

Students' self-directedness in this study characterized by student's effort during the career exploration. Through the interview session, students described her exploration as a process whereby she needs to collect academic and vocational information by her own or to utilize external resources. The technology was considered as the most helpful resource to gain information about her specialization and university options. She used to google and find informative videos from YouTube, such as international students' testimony about strategy for study abroad. Instagram is another medium where she could watch the question and answer session from the alumnae who shared some tips on how 
to be a productive university student. Other than that, the student is affiliating in LINE group which to contain young students who have similar goals to pursue a specialization in a medical study.

I always Google first, I searched for information about the medical study through Google and YouTube, I watched some channels of students from abroad, ... now I'm a member of a LINE group for prospective medical students [Transcript no. 96].

To get more prepared for enrollment test in university, the student took an extra lesson from school and another course from outside. The student felt the need to use the time productively; even she quitted from the organization to focus more on the study. Most of the time, she tried to answer the exercises from preparation books and set the daily target in doing the exercise, which is 30 question a day. Therefore, she criticized about insufficient guidance given by the school, which for that she needs to find extra help from private class and some subject teachers.

The student's interest in leadership and social activity made her actively affiliated in some organization and social works. She fulfilled her interest in writing and Biology by participating in a competition or sending her writing in mass media. She realized her skills acquisition was developed through the regular training, she stated:

That time I took a long time to make an article, approximately two weeks to make it. However, then I tried another time, and I felt after several times I could finish writing earlier than before. Even for my last writing, I just needed three days to accomplish [Transcript no. 58].

The student used feedback from others to monitor and evaluate herself; she considered opinion from others as a suggestion for her self-improvement, not for controlling or switching her objectives.

The student tried to manage her activities and set the essential targets to achieve. The researcher found the student used her journal for six categories: 1) organizational target, which is related to her responsibility in the organization; 2) school target, comprises academic and vocational achievement targets; 3) personal target, which contains her aspiration, personal goals, hobby, to-do list, and her target for skill acquisition; 4) Weekly plan, which includes the list of her daily activities in a week; and 5) self-motivation that presents her written self-reminder and self-development quotes.

\section{Self-Awareness}

Self-awareness is the second qualities of self-directedness revealed from this study. Self-awareness represents the student's understanding of her attribute and other aspects related to her career. This awareness emerged from herself through the learning process and interaction with other people. Student's self-awareness consists of awareness of need, interest, strengths, weaknesses, and challenges.

Awareness of need appeared with student's acknowledgment about personal and learning skills that crucial to be developed. Time-management, self-motivation, hardworking, and persistency were mentioned as critical personal skills. The student considered those skills would help her to perform better in the study and overcome laziness that may lead to demotivation. She said: 
Now I need to enhance my time-management skills, and also self-motivation to overcome burnout when it comes[Transcript no. 90], ...It requires hardworking and persistence because university life is so demanding [Transcript no. 196].

Student's identification of interest helps her to decide her future career, while her awareness of strengths allows her to have more direction in self-actualization. Regarding her interest, she said:

I want to become a medical doctor because it is a combination of science and humanity, ... The most favorite subject is Biology. I would say it is my passion if later, I choose a doctor as my profession [Transcript no. 7B].

Also, she mentioned her strengths, such as writing, public speaking, team working, and communication skill. She also considered her extroverted personality as a supportive quality for her future job. She described as follows:

My personality type is extroverted, I figured out my personality type using an online test, and it was extroverted. So, it will be easier for me to interact with patients and socialize with people [Transcript no. 84].

On the other hand, her realization of her weaknesses and some challenges leads to more anticipation either in the present or future life. She identified weaknesses related to her bad habit that needs to be overcome with effective self-management. She viewed that university life and workplace may be so challenging. She will face the transition from school to university, where the situation will be very much different. The learning culture in university expects the student to be more self-directed compared to school. This changing situation made her more aware of the need for mental preparation and skills acquisition.

I need to find my learning style because, in high school, we are still much more directed by the teacher. However, in university, our success will depend on us; the lecturer will not provide all the learning materials to us; we have the responsibility to learn more about the lesson outside the class. So, I think it is important to master the skill of learning how to learn [Transcript no. 94].

How student actively explores herself, and internal and external encouraging factors influenced the career options. This study discovered that the student had decided her career choice since junior high school and remained consistent with pursuing her goal. She showed efficacy as she mentioned her interest in her future career and how she prepared herself to be qualified to enter higher education level. She acknowledged her strengths as supportive traits to fulfill the requirement of her future job. This tendency might be explained by some findings which stated that self-efficacy and internalized goals are the predictors of students' involvement in career exploration (Blustein \& Noumair, 1996; Betz \&Voyten,1997). External support was admitted by the student as very significant to shape her career aspiration, parents and schools provided support and facilities and encourage her to success. This aligns with a study from Rogers, Creed, and Glendon (2008) who found that high levels of social support and high levels of goal-setting will result in more significant career planning activity, while perceived social support was also found to influence career exploration directly. 
How the student discovered her core interest and pursued the career goals with monitoring of every process reflects self-directedness. However, besides her internal motivation and perceived control, the student still needs support, feedback, and help to be successful in her self-directed career exploration (Gibbons, 2003). Garrison (1992) concluded the natures self-directed learner as "dependent and independent," he noted that students have full responsibility for the internal cognitive process while sharing control of the external goals and activities.

Two essential qualities of self-directed learning appeared from the result, which is the employment of the strategy and self-awareness. How the student involved in and academic, social activities by her initiative showed personal responsibility. She was utilizing various resources and performed self-regulation during the process. As a matter of fact, in self-directed learning individual takes responsibility during the learning process by diagnosing his needs, planning, implementing, monitoring, and evaluating the strategy (Knowles, 1975; Gibbons, 2003; Brockett \& Hiemstra, 1991; Garrison, 1997). In this study, the student was aware of her need to develop essential skills to perform better in learning. Garrison (1992), related to this finding, quoted Smith (1990) that self-directed learning is a center of learning to learn, whereby it includes an active attitude of increasing selfawareness and self-monitoring.

According to Erikson (Patrick, Eliason, \& Samide, 2011; Watson \& McMahon, 2016), those who are encouraged by their parents and teachers will develop feelings of competence and beliefs in their skills. Later on, they will also have high aspirations and career self-efficacy. Besides, Kracke (2002) also noted that child-centered parental behavior is one of the contributors to career exploration initiative.

Some studies have reported the significance of teachers' scaffolding in development of SDL skills (Boyer, 2003; Huynh et al., 2009; Kocaman, Dicle \& Ugur, 2009; Orawiwatnakul, \& Wichadee, 2011; Nguyen \& Gu, 2013; Kranzow \& Hyland, 2016). Four main principles from Francom (2010) might be adopted to improve students' SDL within a context of career exploration in a formal education: (a) match the level of self-directed learning required in learning activities to student readiness; (b) progress from teacher to student direction of learning over time; (c) support the acquisition of subject matter knowledge and self-directed learning skills together; and (d) have students practice selfdirected learning in the context of learning tasks. As a practical step of Francom's recommendation, school through the counseling teacher may provide career guidance based on students' self-directed learning readiness and their career exploration progress. It is because students are varied in their level of responsibility, some students may have higher initiative and reach their career choice earlier, but the rest may be left behind during the process. Paa and McWhirter (2000) pointed out this issue that some students had begun their process of self-exploration; they know that their career expectations are mainly based on their interest, values, and personalities. However, the students cannot figure out how their attributes might have corresponded with specific occupations. In this point, the role of teacher and counselor may take part. 


\section{CONCLUSION}

The results of this present study suggest the importance of developing personal aspiration and support system to foster students actively engage in career exploration. Student's efficacy and motivation is a vital component to start and maintain the effort, while guidance from significant other has a crucial role in facilitating the process. Besides, the whole process of student's self and career exploration reflects self-directedness, which has been developed since a very young age. Regarding this finding, some recommendation might be given to parents and educators; First, for parents: it is suggested to provide support for children's need, expose children with various activities and identify children's strengths from an early age. Second, for educators: there is a need to foster self-directedness through learning activities and to teach other skills related to self-directed learning such as metacognitive and self-regulation.

\section{REFERENCES}

Betz, N. E., \& Voyten, K. K. (1997). Efficacy and outcome expectations influence career exploration and decidedness. The Career Development Quarterly, 46(2), 179-189.

Blustein, D. L., \& Noumair, D. A. (1996). Self and identity in career development: Implications for theory and practice. Journal of Counseling \& Development, 74(5), 433441.

Boyer, N. R. (2003). The learning contract process: Scaffolds for building social, selfdirected learning. Quarterly Review of Distance Education, 4(4), 369.

Boyer, S. L., Edmondson, D. R., Artis, A. B., \& Fleming, D. (2014). Self-directed learning: A tool for lifelong learning. Journal of Marketing Education, 36(1), 20-32.

Dozier, V. C., Sampson Jr, J. P., Lenz, J. G., Peterson, G. W., \& Reardon, R. C. (2015). The impact of the Self-Directed Search Form R Internet version on counselor-free career exploration. Journal of Career Assessment, 23(2), 210-224.

Francom, G. M. (2010). Teach me how to learn: Principles for fostering students' selfdirected learning skills. International Journal of Self-directed Learning, 7(1), 29-44.

Garrison, D. R. (1992). Critical thinking and self-directed learning in adult education: An analysis of responsibility and control issues. Adult Education Quarterly, 42(3), 136-148.

Garrison, D. R. (1997). Self-directed learning: Toward a comprehensive model. Adult Education Quarterly, 48(1), 18-33.

Gibbons, M. (2003). The self-directed learning handbook: Challenging adolescent students to excel. New Jersey: John Wiley \& Sons. 
Grow, G. O. (1991). Teaching learners to be self-directed. Adult Education Quarterly, 41(3), $125-149$

Huynh, D., Haines, S. T., Plaza, C. M., Sturpe, D. A., Williams, G., Rodriguez de Bittner, M. A., \& Roffman, D. S. (2009). The impact of advanced pharmacy practice experiences on students' readiness for self-directed learning. American Journal of Pharmaceutical Education, 73(4), 65.

Kocaman, G., Dicle, A., \& Ugur, A. (2009). Research Briefs. A Longitudinal Analysis of the Self-Directed Learning Readiness Level of Nursing Students Enrolled in a ProblemBased Curriculum. Journal of Nursing Education, 48(5), 286-290.

Kracke, B. (2002). The role of personality, parents and peers in adolescents' career exploration. Journal of Adolescence, 25(1), 19-30.

Kranzow, J., \& Hyland, N. (2016). Self-directed learning: Developing readiness in graduate students. International Journal of Self-Directed Learning, 13(2), 1-14.

Lopulalan, H. (2015). Siswa masih bingung tentukan pilihan jurusan di SNMPTN. Retrieved September 28, 2017, from http://wartakota.tribunnews.com/2015/02/16/siswa-masihbingung-tentukan-pilihan-jurusan-di-snmptn.

Nguyen, L. T. C., \& Gu, Y. (2013). Strategy-based instruction: A learner-focused approach to developing learner autonomy. Language Teaching Research, 17(1), 9-30.

Orawiwatnakul, W., \&Wichadee, S. (2011). A Comparison Of Students' Outcomes In Two Classes: Business Administration Students VS Communication Arts Students Based On Self-Directed Learning Activities. Contemporary Issues in Education Research, 4(5), 23.

Paa, H. K., \& McWhirter, E. H. (2000). Perceived influences on high school students' current career expectations. The Career Development Quarterly, 49(1), 29-44.

Patrick, J., Eliason, G. T., \& Samide, J. L. (Eds.). (2011). Career development in higher education. Charlotte, NC: Information Age Publishing.

Rogers, M. E., Creed, P. A., \& Glendon, A. I. (2008). The role of personality in adolescent career planning and exploration: A social cognitive perspective. Journal of Vocational Behavior, 73(1), 132-142.

Rotherham, A. J., \& Willingham, D. T. (2010). "21st-Century" skills. American Educator, 17(1), 17-20.

Seifert, C., Newbold, C., \& Chapman, R. (2016). Put me in coach: Self-regulated directed learning as tactical power. International Journal of Self-directed Learning, 13(1), 1-11. 
INDONESIAN JOURNAL OF EDUCATIONAL COUNSELING 2019, 3(2), 107-118

Smith, R. M. (1990). Learning to learn across the life span. San Francisco, CA: Jossey-Bass.

Taveira, M. D. C., \& Moreno, M. L. R. (2003). Guidance theory and practice: The status of career exploration. British Journal of Guidance and Counselling, 31(2), 189-208.

Zulkaida, A., Made Taganing Kurniati, N., Retnaningsih, R., Muluk, H., \& Rifameutia, T. (2012). Pengaruh locus of control dan efikasi diri terhadap kematangan karir siswa sekolah menengah atas (SMA). Proceeding PESAT, 2, 1-4. 